\title{
Interneurons Containing Calretinin Are Specialized to Control Other Interneurons in the Rat Hippocampus
}

\author{
Attila I. Gulyás, Norbert Hájos, and Tamás F. Freund \\ Institute of Experimental Medicine, Hungarian Academy of Sciences, Budapest H-1450, Hungary
}

Spine-free calretinin-immunoreactive (CR-IR) interneurons form a subpopulation of GABAergic cells in the rat hippocampus. A characteristic feature of these cells-located in all areas and layers - is the frequent dendro-dendritic and axo-dendritic contacts they form with each other. In this study we examined in detail the connectivity of these neurons by reconstructing their dendritic and axonal arbor and by identifying their postsynaptic targets.

Radially running dendrites of CR-IR cells, located in different layers, intermingled into long braids. An average cell was in contact with dendrites of three to seven other CR-IR cells. Reconstruction of the dendritic trees from six consecutive sections demonstrated that at least 15 cells may participate in a dendro-dendritically connected cluster. Electron microscopical examination revealed that regularly spaced zonula adherentia connect the touching dendrites.

The postsynaptic targets of CR-IR neurons have been examined using postembedding immunogold staining for GABA.
CR-containing GABA-immunoreactive axons of local origin formed multiple symmetrical synaptic contacts (two to five) exclusively on GABAergic dendrites (CR-negative as well as CR-positive). Two to $10 \mathrm{CR}-\mathrm{IR}$ axons may converge onto a single CR-IR neuron, often from cells belonging to the same dendro-dendritically connected cluster. Using double immunocytochemistry, CR-IR cells were shown to heavily innervate calbindin $\mathrm{D}_{28 \mathrm{k}}$-containing interneurons and VIP-containing basket cells but avoided the parvalbumin-containing basket and axo-axonic cells.

The unique connectivity of CR-IR cells may enable them to play a crucial role in the generation of synchronous, rhythmic hippocampal activity by controlling other interneurons terminating on different dendritic and somatic compartments of principal cells.

Key words: GABA; nonpyramidal cells; disinhibition; inhibition; dendro-dendritic contacts; oscillation; gap junction; VIP; cholecystokinin
All cerebral cortical areas are composed of two basic types of neurons. The numerous excitatory principal cells give rise to extensive local as well as distant connections terminating primarily on other excitatory neurons. The less numerous group of GABAergic inhibitory cells arborize in most cases only locally (interneurons), and control the activity of excitatory neurons. In the hippocampus, anatomical and physiological studies revealed a wide spectrum of different inhibitory interneurons with considerable differences both in physiological parameters and in the dendritic, as well as axonal arborization pattern (Kawaguchi and Hama, 1987; Lacaille and Schwartzkroin, 1988a,b; Gulyás et al., 1993a; Han et al., 1993; Buhl et al., 1994; Sík et al., 1995).

Using immunocytochemistry, the interneurons can be classified also on the basis of their neurochemical marker content (calcium binding proteins or neuropeptides). Neurons containing calretinin (CR), parvalbumin (PV), calbindin- $\mathrm{D}_{28 \mathrm{k}}(\mathrm{CB})$, cholecystokinin (CCK), VIP, NPY, and somatostatin (SOM) were shown to form distinct populations (Kosaka et al., 1985; Köhler et al., 1986; Sloviter and Nilaver, 1987; Sloviter, 1989; Sloviter et al., 1991;

Received Dec. 6, 1995; revised Feb. 20, 1996; accepted Feb. 23, 1996.

This work was supported by the Human Frontier Science Program Organization, The Howard Hughes Medical Institute, and OTKA (No. T 5532, T 16942) Hungary. We are grateful to Dr. J. H. Rogers for the antiserum against calretinin, to Dr. T. Görcs for antisera against VIP and CCK, to Dr. K. G. Baimbridge for antiparvalbumin and anti-calbindin, and to Dr. P. Somogyi for the anti-GABA serum. The excellent technical assistance of Mrs. E. Borók, Mrs. A. Z. Szabóné, and Mr. G. Terstyánszky is also acknowledged.

Correspondence should be addressed to Tamás F. Freund, Institute of Experimental Medicine, Hungarian Academy of Sciences, P.O. Box 67, Budapest H-1450, Hungary.

Copyright $(\mathcal{C} 1996$ Society for Neuroscience $0270-6474 / 96 / 163397-15 \$ 05.00 / 0$
Gulyás et al., 1991; Miettinen et al., 1992; Rogers, 1992). The dendritic and axonal arborization patterns of cells containing these neurochemical markers are substantially different. Electron microscopic examination of the postsynaptic targets of PV-, CB-, CCK-, and SOM-IR cells (Nunzi et al., 1985; Katsumaru et al., 1988; Léránth et al., 1990) (A. Gulyás and T. F. Freund, unpublished observations) confirmed the above findings, suggesting that the neurochemical marker content of an interneuron is a reliable marker of its place, and probably of its function, in the hippocampal network.

As a result of multiple studies using different approaches, it appears that there is a high precision in the termination pattern of inhibitory neurons (Somogyi et al., 1983; Katsumaru et al., 1988; Gulyás et al., 1993a; Han et al., 1993; Buhl et al., 1994; McBain et al., 1994; Maccaferri and McBain, 1995; Sík et al., 1995). Inhibitory cells of different classes parcellate the membranc surface of excitatory neurons. It also became clear that simple light microscopical examination of the axonal arbor is insufficient to characterize the output of an interneuron. Cells with remarkably similar axon terminal fields may have different postsynaptic targets identified in the electron microscope, for example, basket versus axo-axonic cells.

The types, distribution and anatomical properties of CR-IR neurons in the hippocampus have been described previously (Gulyás et al., 1992). Two types of CR-IR cells were distinguished. The spine-free CR-IR neurons (second type in Gulyás et al., 1992) regularly formed dendro-dendritic and axo-dendritic contacts with each other, and the axons were studded with irregularly spaced boutons. However, their postsynaptic targets remained unidenti- 
fied. In the present study, we aimed to shed light on the possible roles of spine-free CR-IR cells in the hippocampal inhibitory circuits by correlated light and electron microscopy. Their dendritic and axonal arbors were reconstructed to demonstrate the frequency and extent of dendro-dendritic and axo-dendritic connections, and their exceptional postsynaptic target selectivity was revealed by postembedding immunogold staining for GABA.

\section{MATERIALS AND METHODS}

Male Wistar rats (Charles River, Budapest, $250 \mathrm{gm}$ ) were perfused under deep Equithesine anesthesia (chlornembutal $0.3 \mathrm{ml} / 100 \mathrm{gm}$ ), first with physiological saline $(1 \mathrm{~min})$ and then, in the case of series A $(n=8$ animals), with $300 \mathrm{ml}$ of fixative containing $1 \%$ glutaraldehyde (TAAB), $3 \%$ paraformaldehyde (TAAB), and $0.2 \%$ picric acid in phosphate buffer (PB). For series B the animals $(n=6)$ were perfused using the following fixative: $0.05 \%$ glutaraldehyde, $4 \%$ paraformaldehyde, and $0.2 \%$ picric acid dissolved in $0.1 \mathrm{M} \mathrm{PB}, \mathrm{pH} 7.4$. After fixation, the dorsal hippocampi were dissected together with the overlying neocortex and sectioned on a Vibratome at $80 \mu \mathrm{m}$. In the case of series $\mathrm{A}$, the sequence of the sections was preserved to allow serial reconstruction of axonal and dendritic arbors after immunostaining. After extensive washes in PB, the sections were immersed in a mixture of $25 \%$ sucrose and $10 \%$ glycerol in $0.01 \mathrm{M}$ $\mathrm{PB}$ and freeze-thawed in liquid nitrogen to increase the penetration of antisera during immunostaining. After repeated washes, the sections from animals of series A were treated with $1 \% \mathrm{NaBH}_{4}$ for 30 min to reduce free aldehyde groups and enhance immunostaining.

\section{Pre-embedding immunostaining for $C R$}

The sections from animals fixed with fixative A were incubated first in $20 \%$ NGS (for $45 \mathrm{~min}$ ) and then in rabbit anti-CR antiserum (Rogers, 1989, 1:3000, 2 d). This was followed by incubation in biotinylated goat anti-rabbit IgG (1:100; Vector Laboratories, Burlingame, CA; $4 \mathrm{hr}$ ). Finally, the standard ABC kit (1:100, Vector Laboratories, $3 \mathrm{hr}$ ) was used. The sections were washed three times for $30 \mathrm{~min}$ between each serum. All the washing steps and the dilution of the antisera were performed in 50 mM TBS, $\mathrm{pH} 7.4$, containing $1 \%$ NGS. The peroxidase reaction was developed by 3,3'-DAB-4HCl (DAB, Sigma, St. Louis, MO) as a chromogen.

After the final washes in $\mathrm{PB}$ the sections were treated with $1 \% \mathrm{OsO}_{4}$ for $1 \mathrm{hr}$, dehydrated in ethanol, and embedded in Durcupan (ACM, Fluka, Neu-Ulm, Germany). Selected areas of the embedded sections were re-embedded for further ultrathin sectioning and immunogold stain ing for GABA.

\section{Double pre-embedding immunostaining}

First the CR-IR cells were visualized in sections deriving from animals of series B, using the same method as above, with some alterations. The buffer contained $0.5 \%$ Triton X-100 during the $20 \%$ NGS step and $\mathrm{DAB} /$ nickel reaction was used to visualize CR-IR elements in black (Wouterlood et al., 1987). The first immunoreaction was followed by a second cycle, where either of the following primary antibodies were used: rabbit anti-calbindin $D_{28 k}$ (CB, 1:3000, Baimbridge and Miller, 1982), rabbit anti-parvalbumin (PV, 1:1500, Baimbridge and Miller, 1982), rabbit anti-cholecystokinin (CCK, 1:3000, Gulyás et al., 1990), and rabbit anti-VIP (1:10000; Köves et al., 1991). Biotinylated anti-rabbit IgG (1: 150 , for $3 \mathrm{hr}$ ), and standard $\mathrm{ABC}$ kit (1:100, Vector Laboratories, $3 \mathrm{hr})$ were used in the subsequent steps. The immunoreactive elements were developed using DAB as a chromogen to obtain brown reaction endproduct. The sections were then dehydrated and embedded in Durcupan (without osmium treatment).

\section{Reconstruction of CR-IR cells and their axonal arbor}

Selected CR-IR cells were drawn with the aid of a drawing tube and reconstructed from six $80-\mu$ m-thick serial sections. The cell body and the dendrites were drawn first using $100 \times$ oil immersion objective and the dendrites that were cut on the surface of the sections were marked. Capillaries near the cut ends were also drawn, to serve as landmarks. In the adjacent sections, the same dendrites were identified by matching the capillaries. The axonal arbors of the cells were tracked and reconstructed in the same way.

\section{Postembedding immunogold staining for $G A B A$}

The immunogold staining procedure followed those described by Somogyi and Hodgson (1985) with small modifications, using a well character- ized antiserum against GABA (Hodgson et al., 1985). The steps were carried out on droplets of Millipore-filtered solutions in humid petri dishes, as follows: $2 \%$ periodic acid $\left(\mathrm{H}_{5} \mathrm{IO}_{6}\right)$ for $10 \mathrm{~min}$; wash by dipping in several changes of double-distilled water; $2 \%$ sodium metaperiodate $\left(\mathrm{NaIO}_{4}, \mathrm{BDH}\right)$ for $10 \mathrm{~min}$; wash as before; three times $2 \mathrm{~min}$ in TBS $(\mathrm{pH}$, 7.4); $30 \mathrm{~min}$ in $1 \%$ ovalbumin dissolved in TBS; three times $10 \mathrm{~min}$ in TBS containing $1 \%$ NGS; $1-2 \mathrm{hr}$ in a rabbit anti-GABA antiserum (Code No.9, diluted 1:1000 in NGS/TBS); two times $10 \mathrm{~min}$ TBS; $10 \mathrm{~min}$ in 0.05 $\mathrm{M}$ Tris buffer, $\mathrm{pH} 7.4$, containing $1 \% \mathrm{BSA}$ ) and $0.5 \%$ Tween 20 ; goat anti-rabbit IgG-coated colloidal gold ( $15 \mathrm{~nm}$, Jackson ImmunoResearch, West Grove, PA) for $2 \mathrm{hr}$ (diluted 1:20 in the same buffer); two times 5 min wash in double-distilled water; saturated uranyl acetate for $30 \mathrm{~min}$; wash in four changes of double-distilled water; staining with lead citrate; wash in distilled water. Profiles showing a density of colloidal gold particles at least five times of background level, in two to three adjacent sections, were considered GABA-immunoreactive. Axon terminals forming asymmetrical synapses (presumed glutamatergic) were used to establish background density.

Controls. The specificity of the primary antisera have been tested extensively by the laboratories of origin (see references above). Controls of the methods in the present experiments included replacement of the primary antisera with normal rabbit serum (1:200). In these sections, no staining was visible apart from a faint background limited to the surface of the sections. In double-stained sections, the pattern of immunoreactivity for both antigens was identical to that seen in single-stained material.

Replacement of the GABA antiserum with normal rabbit serum in the postembedding immunogold reaction resulted in a loss of specific staining, that is, no signs of colloidal gold accumulation could be detected over any profiles.

\section{RESULTS}

\section{Distribution of CR-IR elements in the hippocampus}

The distribution and dendritic morphology of CR-IR neurons were similar to that described in detail earlier (Gulyás et al., 1992; Micttinen et al., 1992); therefore, only a short description is given here. Two types of CR-IR neurons can be distinguished on the basis of dendritic morphology and distribution. The cell body and the entire dendritic tree of the first type of cell is restricted to the hilus of the dentate gyrus and to stratum lucidum of the CA3 subfield, and is covered with long, often branching spines. These cells were therefore described as spiny CR-IR cells. Their axons are always myelinated and cannot be visualized by the immunostaining.

In the paper in which the characteristics of these cells were first reported (Gulyás et al., 1992), we used a different antibody against calretinin (Winsky et al., 1989). The antiserum used in the present study showed higher sensitivity and worked also with a fixative containing $1 \%$ glutaraldehyde, allowing us to visualize GABA in the same material with the immunogold procedure.

The other, rather large group (13\% of the hippocampal GABAergic cells; Miettinen et al., 1992) was referred to as spinefree CR-IR cells. The present study deals with this cell type alone; therefore, they will be simply referred to as CR-IR cells. These cells can be found in large numbers in all areas and layers of the hippocampus, even in the hippocampal fissure, showing a rather even distribution. Two to five primary dendrites arise from the multipolar, bipolar or fusiform cell bodies. The smooth, occasionally beaded (see Figs. 1, 4A) dendrites run primarily radially, traversing several layers.

CR-IR axons can be seen in all layers running in all directions, with the radial orientation dominating. The density of axons at the CA1 stratum oriens/alveus border increases, and the axons turn into the horizontal direction. The good quality of axonal staining allowed us to reconstruct relatively long segments of the axonal arborization of CR-IR cells (Fig. $2 A, B$, from a serics of six sections). The morphology of the partially reconstructed axons arising from identified cells was rather variable. Long, rarely branching segments bearing "en passant" boutons were inter- 


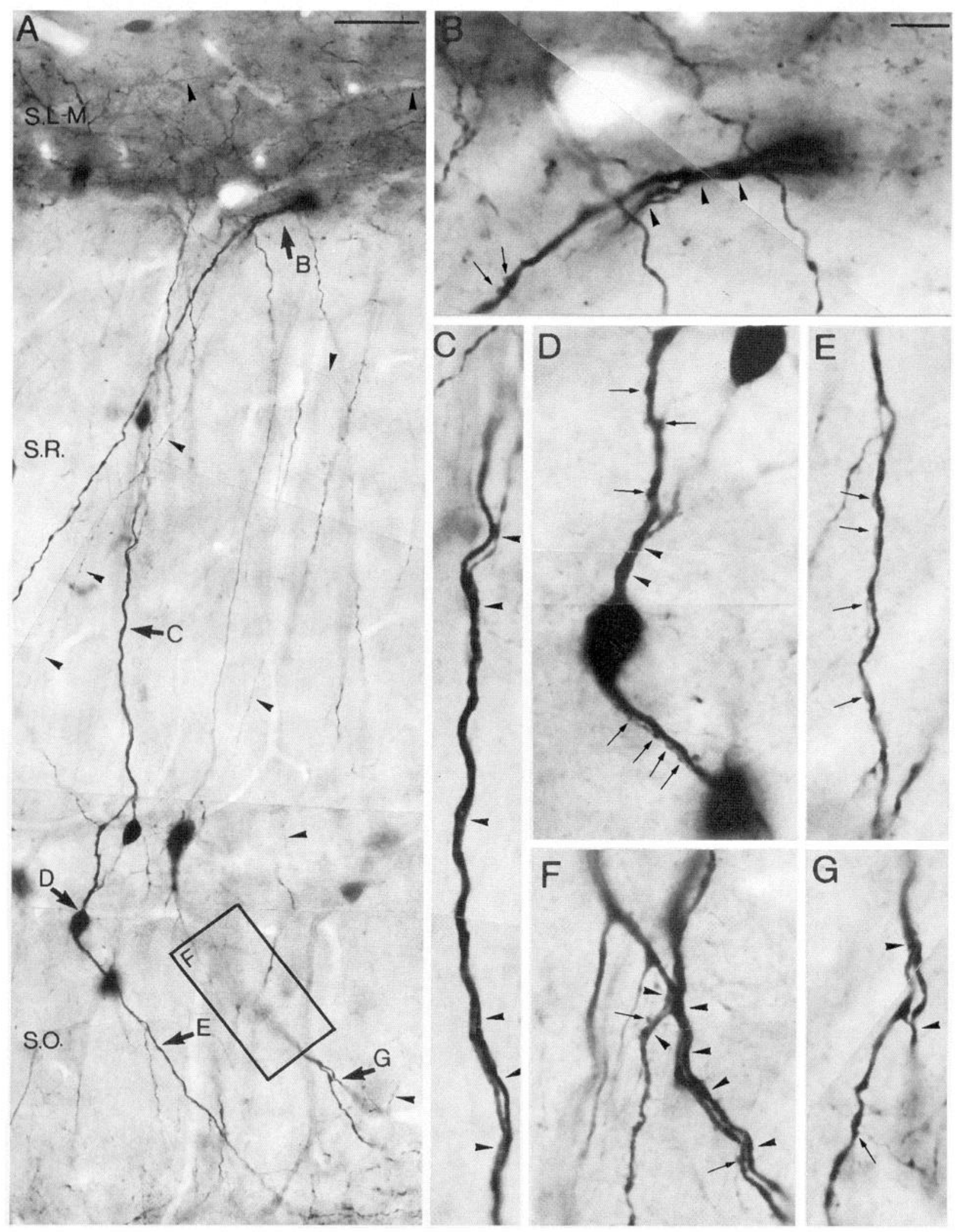

Figure 1. Demonstration of the frequency of dendro-dendritic and axo-dendritic contacts among CR-IR neurons at the light microscopic level. $A$, Low-power micrograph of a 250- $\mu$ m-wide column of the CA1 region. CR-IR axons (arrowheads), dendrites, and somata can be found in all layers. The radially oriented processes often cross several laminar boundaries. Arrows with letters $(B-G)$ identify those parts that are shown at higher magnification. $B-G$, High-power light micrographs of selected examples of dendro-dendritic (arrowheads) and axo-dendritic (arrows) contacts from the area shown in $A$. Note the dendro-dendritic contact in $C$ where two dendrites run attached for more than $200 \mu \mathrm{m}$ (contact continued in top of $D$ ). Scale bars: $A, 50 \mu \mathrm{m}$; $B-G, 10 \mu \mathrm{m}$. 

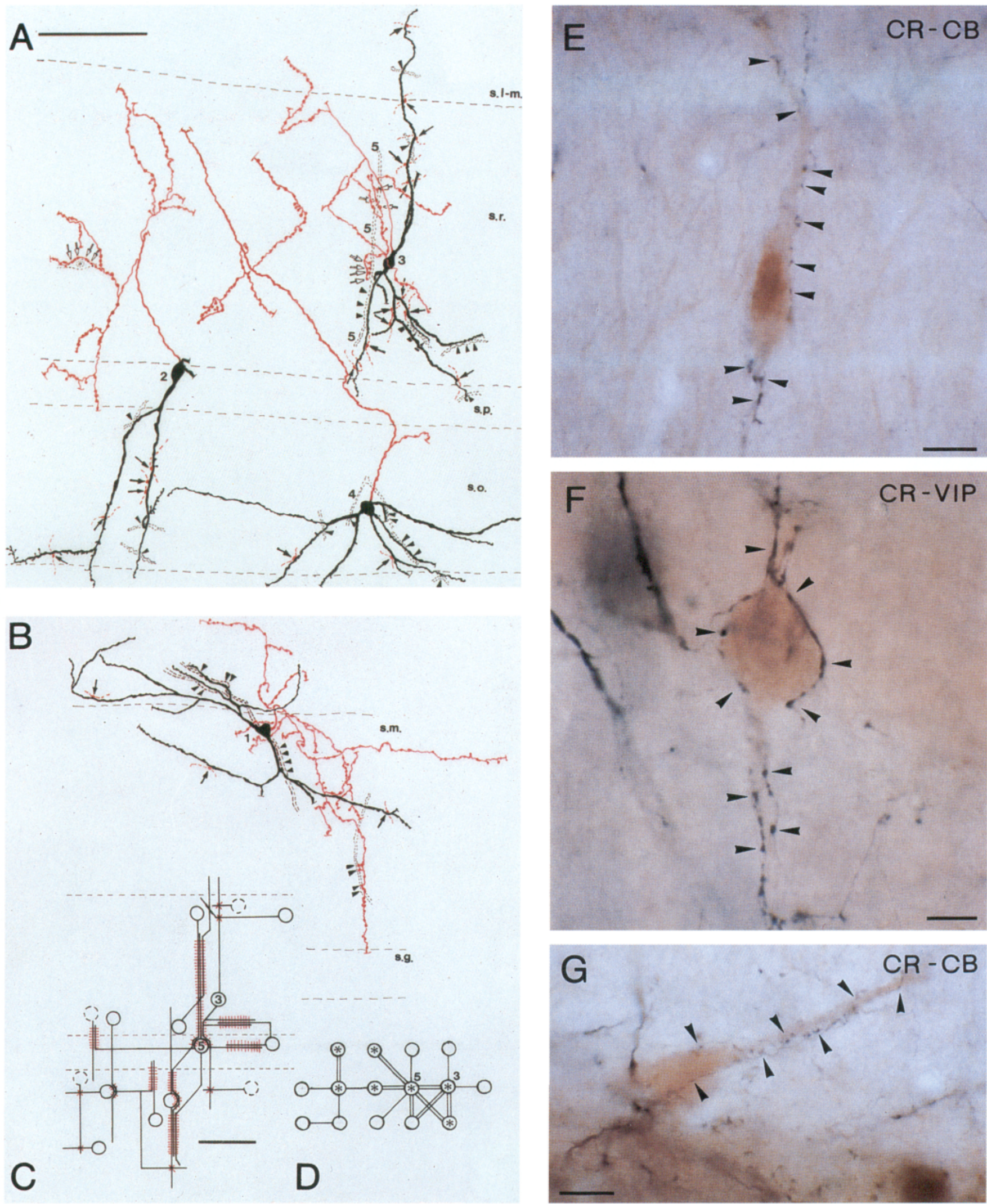

Figure 2. Types of connections established by CR-IR cells. $A, B$, Camera lucida drawing of CR-containing inhibitory interneurons from the CA1 area (2-3 in $A)$ and the dentate gyrus $(1$ in $B)$. Cell bodies and dendrites are drawn in black; axons are drawn in red. The cells were reconstructed from six consecutive, $80-\mu$ m-thick sections. A characteristic property of these cells is that they often form dendro-dendritic and axo-dendritic contacts with each other. Contacting dendrites are shown in the drawings by dotted outlines. Multiple or single arrowheads indicate points where the dendrites ran parallel in close contact, or just touched each other once. An average cell forms dendro-dendritic contact with the dendritic tree of three to seven other CR-IR neurons. Axo-dendritic contacts on cells 1-4 are labeled with arrows. The number of contacts from different CR-IR axons varies between 2 and 10 . In 
spersed with frequently bifurcating branches, which often formed several club-like terminals (see, for example, the axon of cell 4 in Fig. 2A). The distribution of boutons was rather uneven, 10-30 $\mu \mathrm{m}$ long bouton-free segments were followed by highly varicose portions (because of limits of resolution of photographical reproductions the majority of boutons were omitted, leaving only some to demonstrate the inhomogeneous nature of the axons). Axon collaterals of CR-IR cells often formed close appositions (sometimes axonal baskets) around CR-negative somata outside the principal cell layers (see cell 2 in Fig. $2 A$ ).

\section{Numerous dendro-dendritic and axo-dendritic contacts are formed among CR-IR cells}

A remarkable feature of CR-IR cells was that they often formed dendro-dendritic and axo-dendritic contacts with other CR-IR neurons. These contacts were most abundant in the CA1 region (Fig. 2A, cells 2-4; Fig. 1) but could be found regularly in the dentate gyrus (cell 1 on Fig. $2 B$ ) and in the CA3 subfield as well. We examined 70 cells in a single section from the CA1 area and found that all of them (70) were involved in at least one (but usually more) axo-dendritic contacts. Dendro-dendritic contacts were somewhat less numerous, but even in this case 61 of the 70 examined cells were in dendro-dendritic contact with at least one other cell in the section examined. A $250-\mu \mathrm{m}$-wide radial column of the CA1 area in an 80- $\mu$ m-thick section contains $\sim 8-12$ CR-IR cells scattered in all layers (Fig. 1). As demonstrated in the figure, within such a small area several dendro-dendritic contacts can be seen. Ascending and descending dendrites run in close apposition (arrowheads in Fig. $1 B, D, F, G$ ) often for over a $100 \mu \mathrm{m}$ (see the two dendrites in $C$ ) or form a contact limited to one spot. To estimate the number of dendro-dendritic contacts established by a single cell, we reconstructed the dendritic arbor from six $80-\mu \mathrm{m}-$ thick consecutive sections and drew all the contacts formed with other CR-IR profiles. In most cases three to seven contacts were found (of which one to three were multiple) with other CR-IR dendrites. Because five to six cells interconnected by dendrodendritic appositions were often seen in a single section, we tried to estimate the extent of such clusters by reconstructing the dendritic arbors of all those cells. One such cluster is demonstrated in Figure 2, $C$ and $D$. Cell 5 (the outline of one of its dendrites is shown in Fig. $2 A$ ) was drawn first, and the cluster was extended by reconstructing contacted cells followed by those they contacted, recursively. The cluster shown consisted of 15 cells connected by multiple and single dendro-dendritic contacts. Another cluster, containing 13 cells (not shown here), was also reconstructed. However, we used only a series of six sections for the reconstruction; therefore, some of the dendritic trees are incomplete. Thus, the number of cells participating in a dendrodendritically connected cluster is probably underestimated.

The frequency of axo-dendritic contacts between CR-IR cells is also illustrated in Figures 1 and $2, A$ and $B$. The primarily radially running axons form multiple contacts with dendrites (Fig. $1 B, D-G$; see also in Figs. $2 A, 4$ ) and/or somata (up to 20 boutons) of other CR-IR neurons. A cell can be innervated by $2-10$ different CR-IR collaterals, many of them providing multiple contacts. We found examples when both dendro-dendritic and axodendritic contacts were formed between two CR-IR neurons (e.g., as between cell 3 and dendrite 5 in Fig. $2 A$ ).

\section{Ultrastructure of dendro-dendritic contacts}

To reveal the fine structure of dendro-dendritic contacts, arcas containing closely apposed dendrites were selected, re-embedded (from the CA1 region and the $\mathrm{DG}$ ) and serially sectioned for electron microscopy. Examination of several of these dendritic segments demonstrated that numerous regularly spaced zonula adherentia interlock the touching dendrites (Fig. 3A,C,D, arrowheads). This type of membrane specialization is characterized by a thick $(25-30 \mathrm{~nm})$ dense projection on both membranes intracellularly, and dense material is present also in the subjunctional extracellular space, which has dimensions similar to those of a synaptic cleft. Vesicles are never found to accumulate near these junctions. The zonula adherentia are positioned at 5-10 $\mu \mathrm{m}$ from each other and can be invariably found where the membranes of two dendrites first join and before they separate, as if they served as a clip to attach the dendrites. Tens of micrometers of dendro-dendritic contacts were thoroughly examined in serial sections in search for gap junctions. However, because of the strong immunoreactivity in both of the contacting dendrites the preservation of the membrane was insufficient for an unequivocal demonstration of this fine membrane specialization. Although in some cases we found contacts resembling gap junctions (Fig. $3 B$, double arrowheads), they were distorted by the immunoreaction endproduct. Thus, their presence and frequency of occurrence between CR-IR dendrites need to be further investigated. Besides the zonula adherentia, we often found CR-IR axon terminals intercalated between the contacting dendrites and forming symmetrical synapses on one or both of them (Fig. $3 C, D$, arrow). Such intercalated contacts were mostly located in the proximity of zonula adherentia.

\section{Multiple symmetrical synapses are formed between identified CR-IR axons and dendrites}

CR-IR axons involved in forming axo-dendritic contacts were often traced back to other CR-IR interneurons (see Fig. $2 A$, cell 3 ). The cell that gave rise to the axon was often located in different layers than the target neuron, that is, distant pairs of cells such as stratum oriens/stratum radiatum or stratum pyramidale/stratum lacunosum-moleculare pairs were common.

The multiple contacts formed between the axon of cell 3 and dendrite 5 (in Fig. $2 A$ ) was serially sectioned for electron microscopy to examine the presence of synapses. All the seven terminals

$\leftarrow$

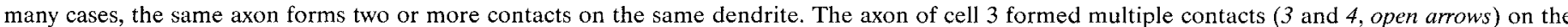

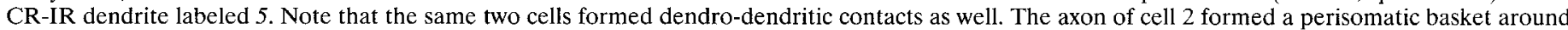

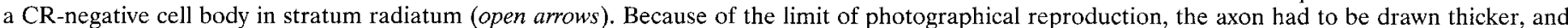

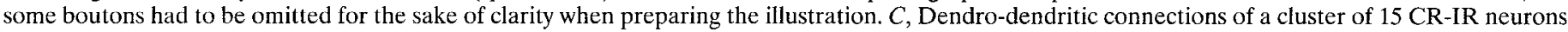

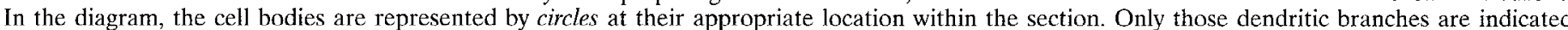

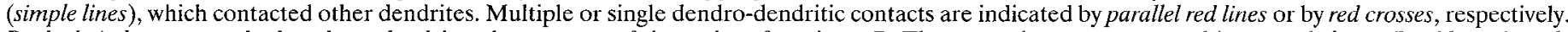

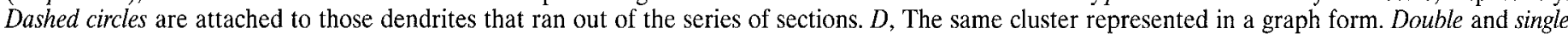

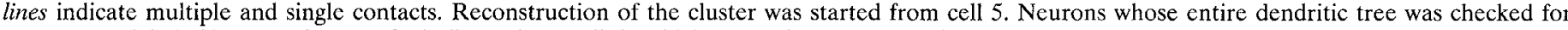

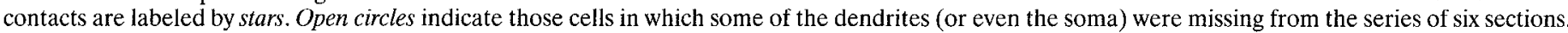

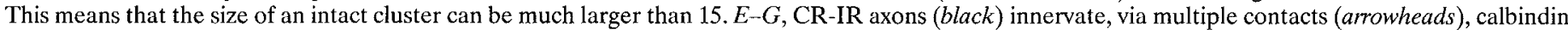
$\mathrm{D}_{28 \mathrm{k}}$-containing interneurons $(E, G)$, as well as VIP-immunoreactive basket cells $(F)$. Scale bars: $A, C, 200 \mu \mathrm{m} ; E-G, 10 \mu \mathrm{m}$. 

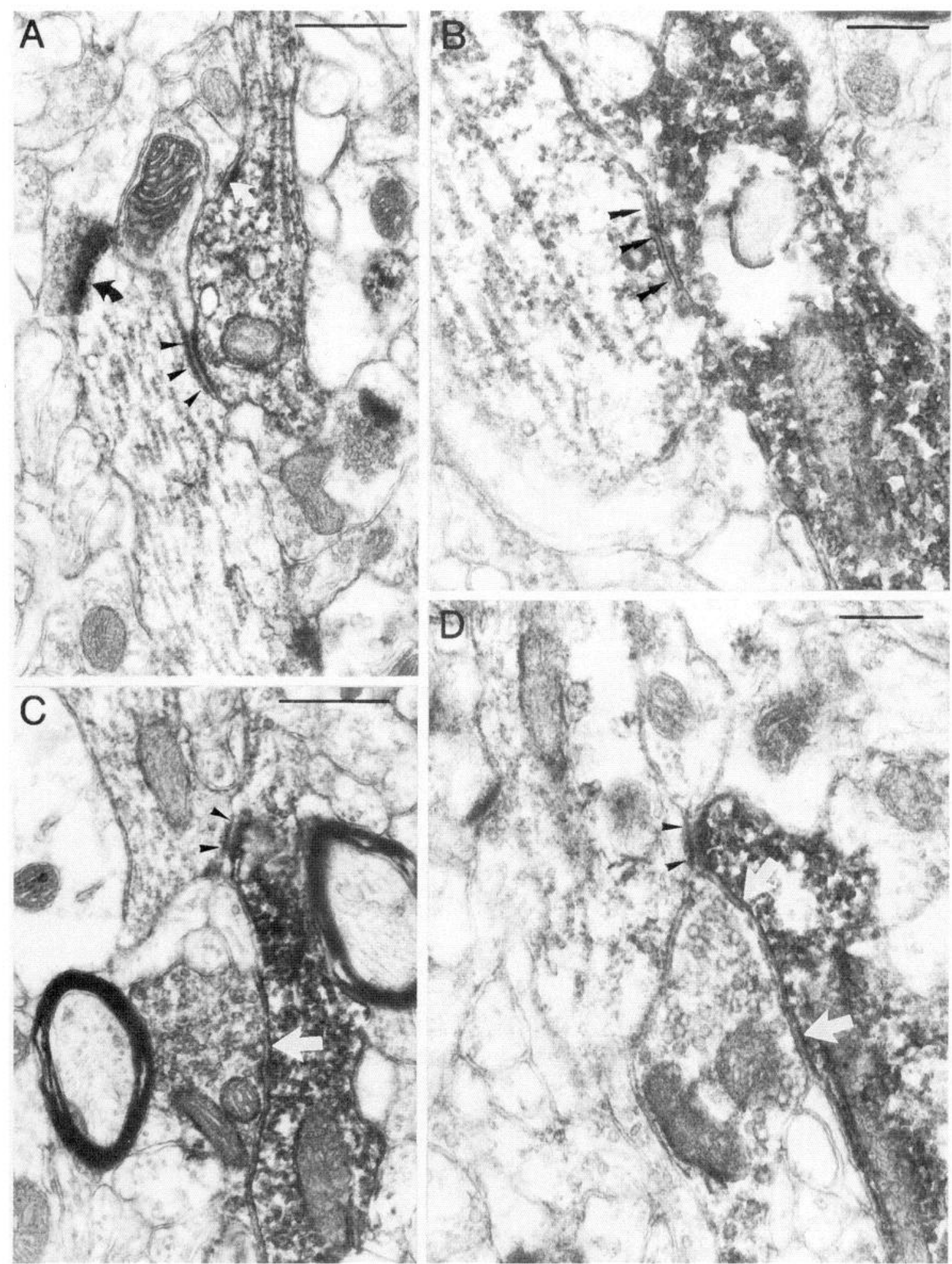

Figure 3. Ultrastructure of dendro-dendritic contacts between CR-IR dendrites. In $A, C$, and $D$, zonula adherentia (arrowheads) are formed between the contacting dendrites. In $C$ and $D$, one of the CR-IR dendrites receives an additional axo-dendritic contact (white arrow, symmetrical synapse), next to the punctum adherens, from CR-IR axon terminals. The dendrites also receive asymmetrical synapses from unlabeled terminals (curved white and black arrow in $A$ ). The membrane segments labeled with double arrowheads in $B$ appear to form a gap junction. However, because of the diamino-benzidine precipitate on the membranes, the type of the specialization is equivocal. Scale bars: $A, B, 0.5 \mu \mathrm{m} ; C, D, 0.25 \mu \mathrm{m}$.

established symmetrical synapses on the postsynaptic dendrite (Fig. 4). The presence of gold particles in the axon and the postsynaptic dendrite indicated that they were both immunoreactive for GABA. Boutons 1-4 were located at the end of short side branches of the axon (club-like terminals, similar to long pyramidal cell dendritic spines), whereas boutons 5-7 were "en passant" terminals asymmetrically positioned on the main axon, with a bias toward the postsynaptic dendrite. Thus, the axon appears as if it 

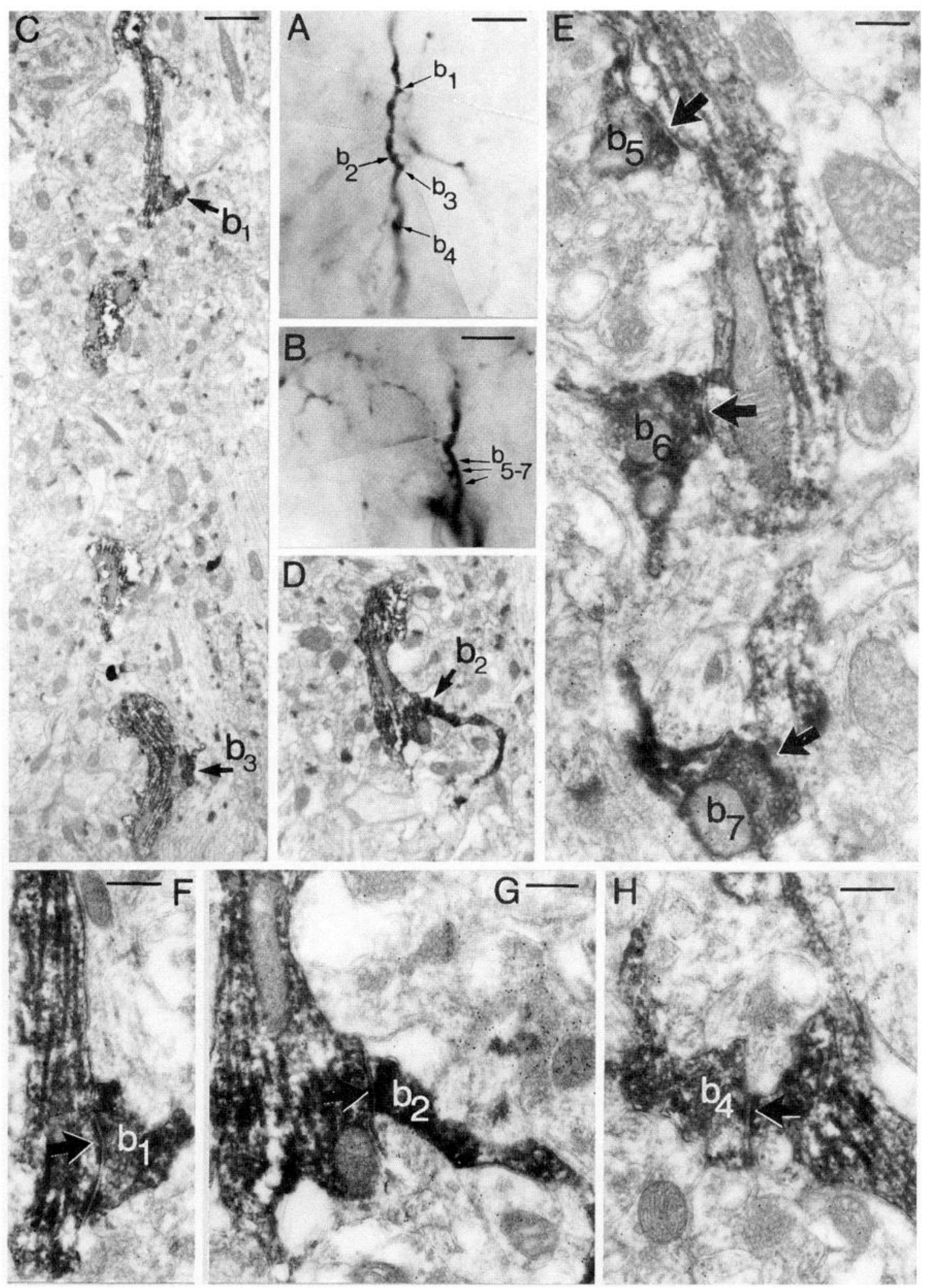

Figure 4. Multiple contacts between CR-IR axons and dendrites. $A, B$, Two segments of a dendrite (cell 5 in Fig. $2 A$ ) are shown at low power. The axon of cell 3 (of Fig. 2) climbs along the dendrite and establishes seven contacts $\left(b_{1-7}\right)$ with it, via club-like $\left(b_{1-4}\right)$ and "en passant" $\left(b_{5-7}\right)$ terminals. $C$, Low-power electron micrograph of the dendritic segment shown in $A$, demonstrating the contacts formed by boutons $b_{1}$ and $b_{3}$. $D$, The same dendritic segment from another section with bouton $b_{2}$. E-H, Boutons 1,2, and 4-7 are shown at higher magnification to form symmetrical synapses (arrows) on the same postsynaptic dendrite (cell 5). The synaptic cleft is not visible in the case of $b_{7}$ in this section but has been confirmed by goniometer. The accumulation of gold particles in the presynaptic axons and the postsynaptic dendrites clearly indicate their GABA immunoreactivity. However, because of the masking effect of the pre-embedding CR-immunoreaction endproduct, the GABA immunoreactivity is weaker in these elements than in unstained profiles (see Figs. 5, 6). Scale bars: $A, B, 10 \mu \mathrm{m} ; C, D, 1 \mu \mathrm{m} ; E, 0.5 \mu \mathrm{m} ; F, G, 0.25 \mu \mathrm{m}$. 
were "reaching" toward the postsynaptic dendrite. Besides the CR-containing axon terminals, several other boutons were found to establish further symmetrical and asymmetrical synapses on the CR-IR dendrites.

\section{CR-IR axon terminals selectively innervate GABAergic neurons}

To obtain unbiased data for the distribution of postsynaptic targets of identified CR-IR cells, bouton-rich segments of the axonal arbors of cells (cells 1-3 in Fig. 2) from the dentate gyrus and CA1 area were serially sectioned for electron microscopy and postembedding GABA immunogold reaction. The 45 identified axon terminals formed symmetrical synapses on dendrites with medium diameter (Fig. 5). All except one postsynaptic dendrites proved to be GABA-positive, the remaining one was unidentified because of inconsistent GABA labeling in serial sections. In long section series it became evident that the reconstructed CR-IR axons were climbing along the GABAergic dendrites, and placed multiple (at least two to four) synapses onto the same shaft (Fig. 5A-D). The postsynaptic dendrites received further symmetrical (GABA positive) and asymmetrical (GABA negative) synapses from unlabeled axon terminals as well.

We also examined 17 randomly selected boutons from the outer molecular layer of the dentate gyrus and from stratum radiatum of the CA1 subfield. These terminals, similarly to the identified ones, terminated solely on GABAergic dendrites, often participating in multiple contacts.

\section{CB-, CR-, and VIP-immunoreactive interneurons are heavily innervated by CR-IR axons}

GABAergic interneurons can be subdivided into several functionally distinct subpopulations on the basis of their input-output features, which correlate well with neurochemical characteristics. It is of importance whether CR-IR cells distinguish among these subpopulations of interneurons or they innervate GABAergic neurons of any type. This question was investigated by doubleimmunostaining for CR (Ni/DAB, black), and the markers of various interneuron subpopulations, that is, $\mathrm{CB}, \mathrm{PV}, \mathrm{CCK}$, and VIP. The distribution and morphology of the above cell types has been described already in several earlier studies; therefore, only a brief description is given here.

CB-IR intcrncurons (Cclio, 1990; Sloviter ct al., 1991; Tóth and Freund, 1992) can be found in moderate numbers primarily in strata oriens and radiatum of the CA3 and CA1 subfields. In the CA1 region $\mathrm{CB}-\mathrm{IR}$ interneurons are clearly distinguishable from the weaker stained CB-containing pyramidal cells. A small number of cells can be found also in stratum moleculare of the dentate gyrus, but it is rather difficult to see them because of the strong immunoreactivity of granule cell dendrites. In stratum radiatum of CA1-3, the cells have a multipolar morphology, whereas in stratum oriens several of them have horizontally oriented dendritic trees. In the CA1-3 subfields, their axons arborize in the dendritic region of pyramidal cells (Sík et al., 1995) (Gulyás and Freund, unpublished observations).

The distribution and types of VIP-IR neurons have also been described elsewhere (Köhler, 1982; Léránth et al., 1984; Acsády et al., 1995a,b). They are present in each subfield and layer of the hippocampus, but their number is only half of that of CR-IR cells. Using thc criteria of Acsády ct al. (1995a,b) three subgroups of VIP-containing cells were distinguished: (1) medium to small cells in stratum pyramidale and stratum radiatum with dendritic tuft in stratum lacunosum-moleculare and axon projecting to the border of stratum oriens/alveus; (2) medium-size cells similar to CR-IR cells in stratum radiatum and lacunosum-moleculare, with axon arborizing in stratum radiatum; and (3) large cells located within or near stratum pyramidale with axon arborizing in the perisomatic region of pyramidal cells. This latter cell type also contains CCK (Acsády et al., 1995a,b). Similar cell types were found in the dentate gyrus as well (Hájos et al., 1995).

PV-IR neurons can be found in large numbers in the principal cell layers of all hippocampal regions (Kosaka et al., 1987; Katsumaru et al., 1988; Celio, 1990; Sloviter et al., 1991). Their dendrites run radially and span all layers of the given subfield. The axons arborize in stratum pyramidale and proximal oriens, terminating on the somata and axon initial segments of pyramidal cells. The same sites of granule cells are the targets of PV-positive axons in the dentate gyrus.

CCK-positive cells have a medium-to-large soma, and bitufted dendritic tree in all subfields and layers of the hippocampus. The vast majority have an axon arborizing in stratum pyramidale (basket cells, also containing VIP), whereas a smaller proportion has a sparse arbor in stratum radiatum and oriens (Kosaka et al., 1985; Nunzi et al., 1985; Sloviter and Nilaver, 1987).

In the CA1 and CA3 regions, where numerous CB-IR interneurons could be reliably examined, CR-IR axon collaterals were found to heavily innervate the CB-IR cells (Fig. $2 E, G$ ). From the 142 CB-IR cells found in 11 sections of CA1 area, 131 received multiple contacts from CR-IR axons, which crept along the dendrites and somata of the target neurons, and formed 15-30 terminals (arrowheads in Fig. $2 E, G$ ) on them. In contrast to CB-IR interneurons, dendrites or somata of $\mathrm{CB}$-containing pyramidal cells were avoided by CR-IR boutons in the CA1 region. In CA3 46 CB-IR neurons out of 52 examined were innervated by multiple CR-IR axon terminals. CB-IR cells, which did not receive such innervation from CR-IR axons, were mainly located in stratum oriens in both cases.

The basket type of VIP-IR cells, that is, those with large somata, and axons surrounding pyramidal cell bodies, were also heavily innervated by CR-IR axons (Fig. $2 F$ ). All of the 68 identificd VIP-IR basket cells (50 in the CA1 and 18 in the CA3 region, detected in 10 sections) were densely covered by terminals of CR-IR axons (23-68 boutons per cell). A smaller number of VIP-IR cells with oriens/alveus projection were also innervated by climbing fiber-like CR-IR axons. This was expected because these cells are known to also contain CR. In the dentate gyrus the innervation of VIP-IR basket cells was much less pronounced (only two to three boutons per cell). In Ammon's horn, CCK-IR basket cells were also covered by CR-IR axon terminals, confirming the results of VIP-CR double staining concerning VIPcontaining basket cclls, bccausc VIP and CCK are known to coexist in this basket cell population (Acsády et al., 1995a).

The contacts between CR-IR axons and neurochemically identified target cells were confirmed to be synapses by correlated electron microscopy. This is illustrated by a VIP-IR basket cell shown in Figurcs $2 F$ and 6 , which received 34 terminals from an identified CR-IR axon. Seven of the terminals were serially sectioned for electron microscopy, and all of them proved to form symmetrical synapses (Fig. 6).

In contrast to the strong innervation of the above cell types, PV-IR cells were largely avoided by the CR-IR terminals in all areas of the hippocampus. If occasional contacts were found, they were all made by single terminals. This conclusion is based on a thorough examination of 16 sections from two animals, which 

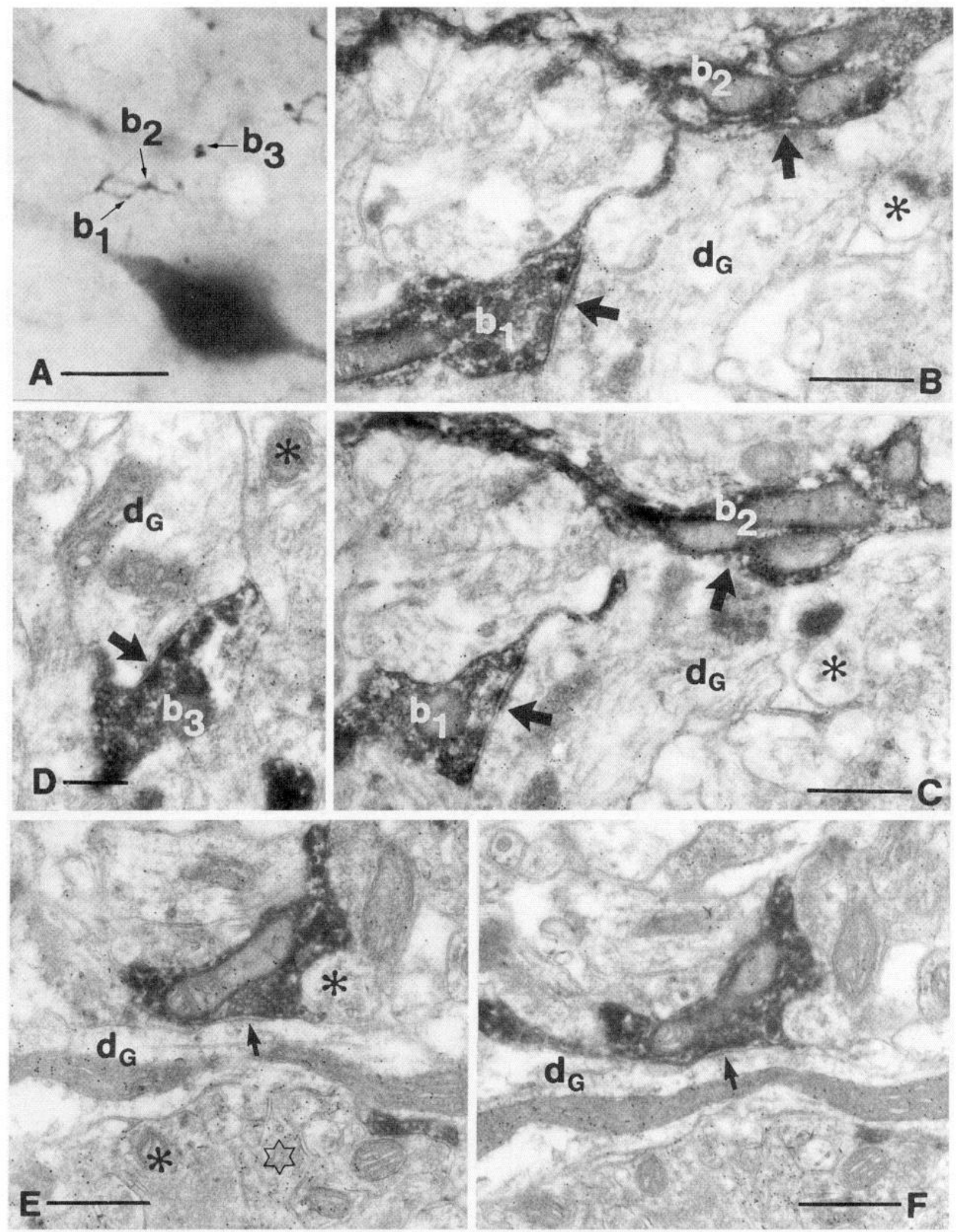

Figure 5. GABAergic dendrites are the postsynaptic targets of CR-IR axon terminals in the CA1 and CA 3 subfield. $A$, Three boutons $\left(b_{1-3}\right)$ of cell 2 (of Fig. 2) are shown in the light micrograph. $B-D$, Examination of the three boutons in the electron microscope revealed that they contact the same GABA-positive postsynaptic dendrite. As shown in the two consecutive sections of boutons 1 and $2(B, C)$ and of bouton $3(D)$, the CR-IR axon terminals formed symmetrical synapses (arrows) with the GABA-containing dendrite $\left(d_{G}\right) . E, F$, GABA-positive axon terminal of cell 1 in Figure $2 B$. The CR-containing axon is shown in two consecutive sections, forming a symmetrical synapse (arrow) on a GABA-positive dendrite $\left(d_{G}\right)$ in stratum moleculare. Asterisks and a star mark GABA-negative and GABA-positive elements in the neuropil. Scale bars: $A, 10 \mu \mathrm{m} ; B-F, 0.5 \mu \mathrm{m}$. 

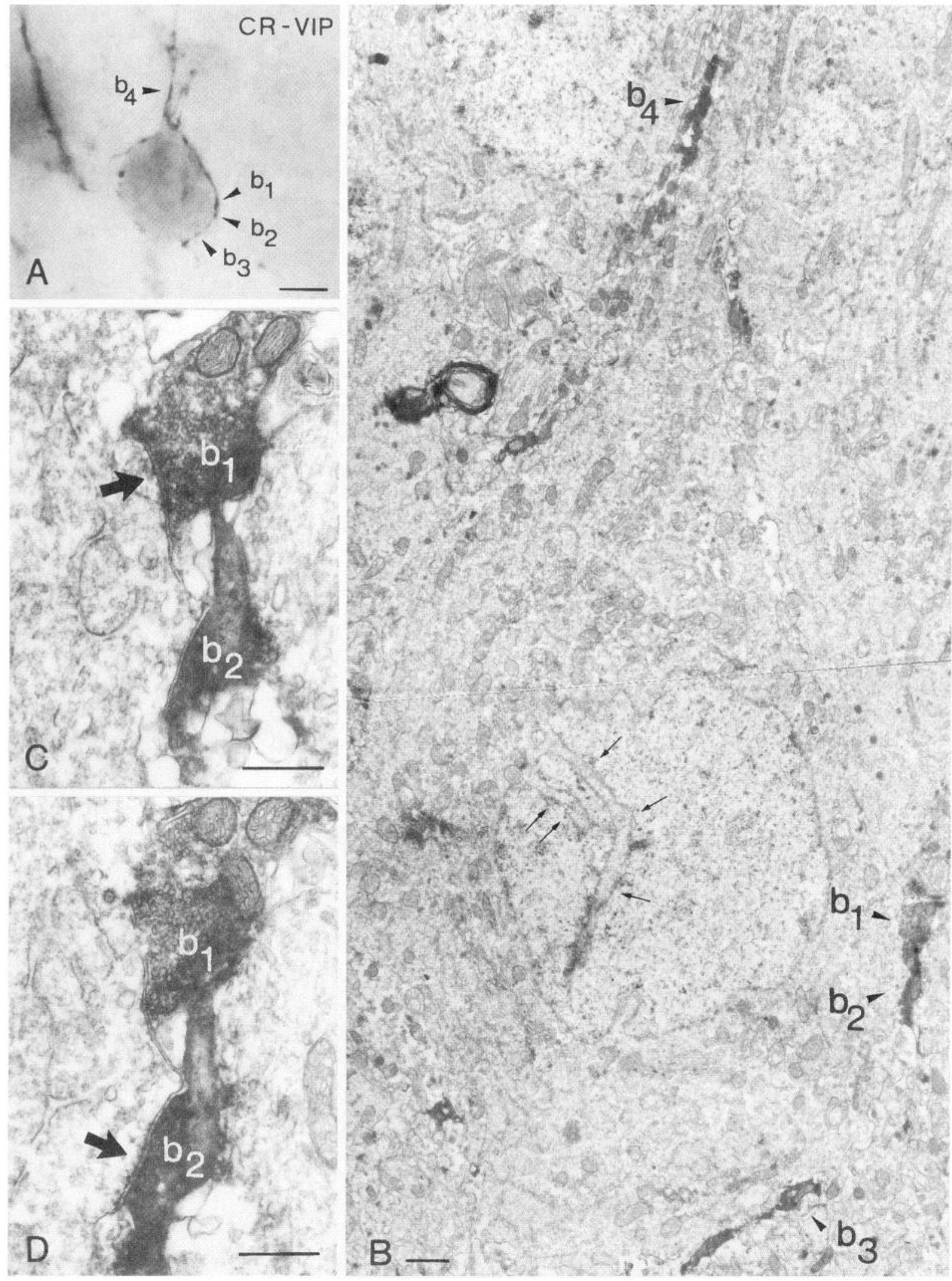

Figure 6. Light and electron microscopic demonstration of multiple contacts between CR-IR axons and a VIP-IR basket cell. Four of the numerous ( $n$ $=34)$ CR-IR axon terminals $\left(b_{I-4}\right.$ in $A$ and $B$, labeled by dense $\mathrm{DAB} / \mathrm{Ni}$ precipitate) are shown to form symmetrical synapses in the perisomatic region of a VIP-IR basket cell (outlined by the weaker DAB precipitate). The cell was located at the stratum pyramidale/stratum oriens border (the same cell is shown in Fig. $2 F$ in color). Invaginations on the nuclear membrane (arrows in $B$ ) are characteristic features of GABAergic interneurons. The high-power electron micrographs in $C$ and $D$ show two symmetrical synapses (arrows) formed by boutons $b_{1}$ and $b_{2}$ in nearby sections. Scale bars: $A, 10 \mu \mathrm{m} ; B, 1 \mu \mathrm{m}$; $C, D, 0.5 \mu \mathrm{m}$ 
contained several hundred PV-IR neurons and good quality axonal staining for CR.

\section{Termination pattern of CR-IR fibers in stratum lacunosum-moleculare}

A large number of CR-IR axons could also be found in stratum lacunosum-moleculare of the CA3 and CA1 subfields. However, the number of terminal varicosities formed in this layer was lower than in other layers. The majority of the axons ran in parallel bundles, and had no terminal varicosities.

The postsynaptic targets of axons in this layer were also studied in the electron microscope. CR-IR profiles with axonal morphology ( $n$ $=60$ ) were of three types. Axons of the first and second group formed synapses with dendrites, and accounted for a third of CR-IR profiles observed in single sections. Axons of the first group formed symmetrical synapses on GABA-positive dendrites (Fig. $7 A, B, n=9$, $15 \%$ of all examined elements), whereas terminals of the second targeted GABA-negative dendrites, and formed asymmetrical synapses with characteristically pronounced postsynaptic densities (Fig. $7 C, D, n=11,18.3 \%)$. The majority of the axonal profiles $(n=40$, $66.7 \%$ ), forming the third group, were nonvaricose, contained no synaptic vesicles, and were often myelinated (axons labeled with arrowhead and curved arrow in Fig. $7 E$ ).

\section{DISCUSSION}

The major findings of the present study are the following. (1) CR-IR neurons form large dendro-dendritically and axodendritically connected clusters. The dendritic braids are held together by regularly spaced zonula adherentia, whereas the dendrites receive multiple symmetrical synapses from several other CR-IR neurons, often from members of the same cluster. (2) CR-IR cells show a high degree of target selectivity; they innervate mostly if not exclusively other GABAergic neurons via multiple synapses. The innervated subclasses-in addition to other CR-IR cells-include CB-immunoreactive neurons, basket cells containing both VIP and CCK, and VIP-positive cells (also containing CR) that project to the stratum oriens/alveus border.

\section{Origin and light microscopy of CR-IR axons}

The antiserum used here visualized the dendritic and axonal arbor of CR-IR cells in more detail than the one in our earlier report (Gulyás et al., 1992). This allowed us to reconstruct relatively large portions of the axonal arbor and to combine CR immunostaining with postembedding GABA immunogold staining.

We could demonstrate that-except for the dense CR-IR fiber networks at the stratum granulosum/moleculare border of the dentate gyrus, at the CA2/CA3a border, and in stratum lacunosummoleculare of CA1-3 (see below) - hippocampal CR-IR axons are of intrinsic origin.

Irregular distribution of boutons, the presence of club-like terminals, and the asymmetrically positioned "en passant" terminals are characteristic features of the intrinsic CR-IR axons. Other groups of inhibitory cells terminating primarily on principal cell dendrites, such as CB-IR cells, SOM-IR cells, and most of those visualized by intracellular filling (Gulyás et al., 1993d; Halasy and Somogyi, 1993; Han et al., 1993), as well as pyramidal cell axons, the targets of which are most often also pyramidal cells (Gulyás et al., 1993b; Sík et al., 1993), show a rather homogeneous distribution of primarily "en passant" boutons. CR-IR axons may form groups of "en passant" boutons, or club-like terminals, to contact their sparsely distributed nonpyramidal targets. In contrast, cells whose targets are the abundant pyramidal cells place their boutons relatively evenly. Thus, irregular bouton distribution may be an indication of a cell's target selectivity already at the light microscopical level. Indeed, two subpopulations of VIP-IR cells with similar irregular bouton distribution proved to innervate predominantly other GABAergic interneurons (Acsády et al., 1995a,b).

CR-IR axons of extrinsic origin were identified in the dentate gyrus at the stratum granulosum/moleculare border and in strata pyramidale and oriens of the CA2-CA3a border. These axons arise from the supramammillary nucleus both in the rat (Maglóczky et al., 1994) and monkey (Nitsch and Léránth, 1993) and terminate on principal cell dendrites and somata forming asymmetrical synapses with pronounced postsynaptic densities. The origin of main axon trunks and boutons forming asymmetrical synapses in stratum lacunosum-moleculare is equivocal. However, the projection from the nucleus reuniens of the thalamus, which contains CR-IR neurons (Jacobowitz and Winsky, 1991), is known to terminate in this layer, forms asymmetrical synapses (Wouterlood et al., 1990), and thus represent the most likely candidate.

\section{Inhibitory control of interneurons terminating in different soma-dendritic domains of principal cells}

GABAergic input onto hippocampal interneurons from intrinsic (Nunzi et al., 1985; Gulyás et al., 1993a; Acsády et al., 1995b; Hájos et al., 1995; Sík et al., 1995), as well as extrinsic (Freund and Antal, 1988; Gulyás et al., 1990) sources has been demonstrated anatomically. These interactions were characterized and confirmed by intracellular recordings from interneurons (Misgeld and Frotscher, 1986; Lacaille et al., 1987; Lacaille and Schwartzkroin, 1988a,b; Michelson and Wong, 1991; Tóth et al., 1995) as well. In the case of the septohippocampal pathway, a precise selectivity for hippocampal interneurons has been demonstrated (Freund and Antal, 1988). The distribution of postsynaptic targets was analyzed in the case of several hippocampal and cortical interneuron groups. The proportion of GABAergic targets was found to be rather low for basket and dendritically terminating cells (5-15\%, Nunzi et al., 1985; Somogyi and Soltész, 1986; Gulyás et al., 1993a; Halasy and Somogyi, 1993; Sík et al., 1995), whereas chandelier cells innervate axon initial segments exclusively of pyramidal cell origin (Somogyi et al., 1983).

Here we demonstrated that hippocampal CR-IR interneurons terminate exclusively on interneurons (involving CR-IR cells themselves) forming multiple contacts. Using double immunocytochemistry, the target interneuron subpopulations were also identified. CB-IR interneurons and VIP(CCK)-IR basket cells were the predominant targets of CR-IR axons. CB-containing inhibitory cells were shown to innervate the middle and distal segments of principal cell dendrites both in the hippocampus (Gulyás and Freund, unpublished observations) and the neocortex (DeFelipe et al., 1989). Basket cells containing VIP and CCK (Acsády et al., 1995a) were also heavily innervated, whereas the PV-IR basket and axo-axonic cells were avoided by CR-IR axons. This selectivity, and the fact that the serotonergic raphehippocampal afferents make similar distinction (innervate VIPcontaining basket cells, but ignore PV-containing neurons; Freund et al., 1990) suggests that perisomatic inhibition of principal cells arises from two functionally distinct basket cell populations, which are under different local and subcortical control (Ribak et al., 1990; Acsády et al., 1995a,b).

In the study of Acsády et al. (1995a,b), two further subpopulations of VIP-IR interneurons were identified with selectivity for GABAergic neurons. One group of cells were shown to be immunoreactive also for $\mathrm{CR}$, and innervated the somata and horizontally running dendrites of cells located at the stratum oriens/alveus 

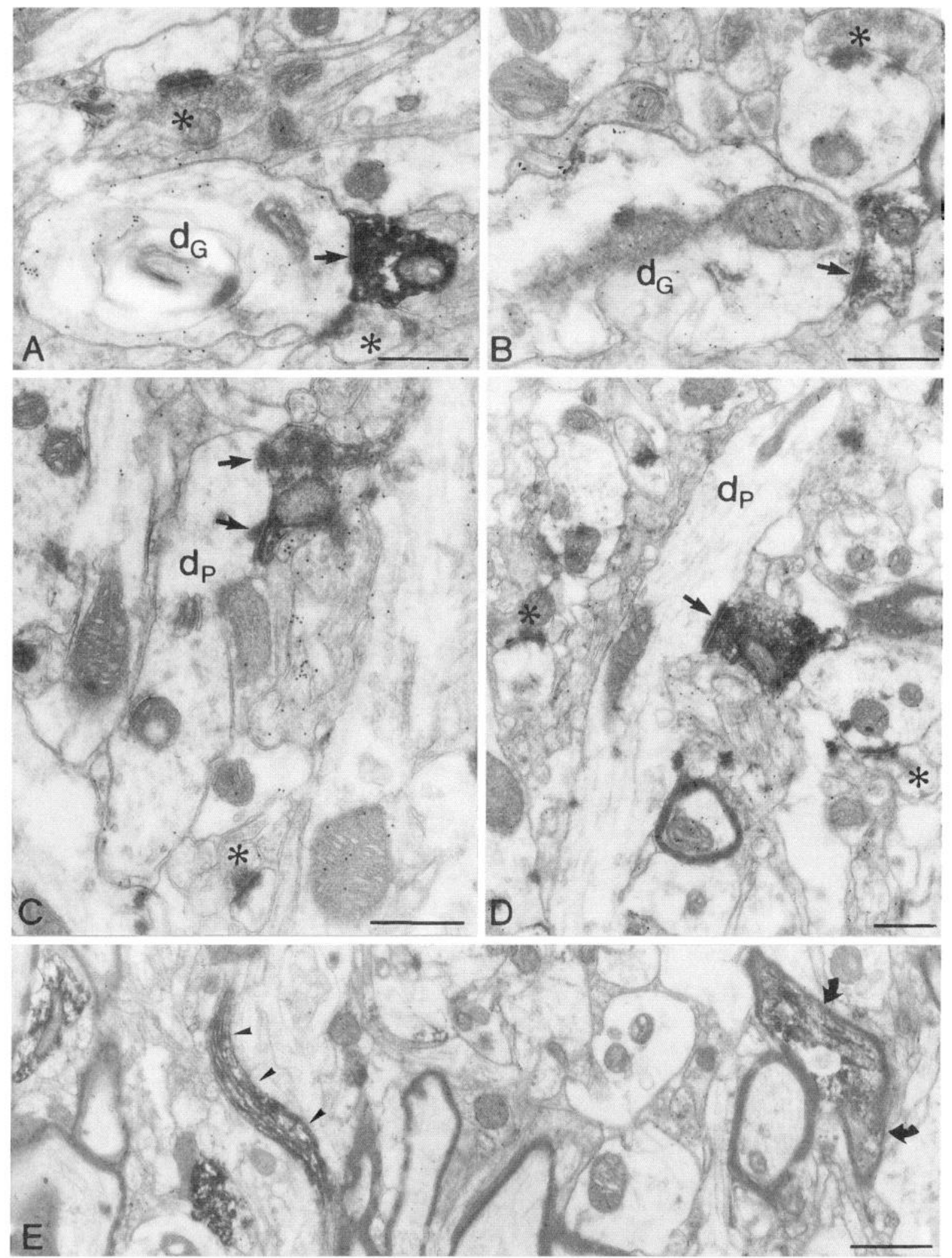

Figure 7. Targets of unidentified CR-IR axons in stratum lacunosum-moleculare of the CA1 subfield. In this area, a majority of immunoreactive axonal profiles were either myelinated (curved arrows in $E$ ) or were preterminal axons (arrowheads in $E$ ), without terminal enlargement. When CR-IR axons formed synaptic varicosities ( $\sim 30 \%$ of the profiles), two types of terminals could be distinguished ( $\sim 15-15 \%)$. In half of the cases, GABA-positive presynaptic boutons formed symmetrical synapses (arrows in $A$ and $B$ ) on GABA-positive dendrites $\left(d_{G}\right)$. In the other half of the cases, GABA-negative CR-positive terminals formed characteristic asymmetrical synapses with pronounced postsynaptic densities (arrows in $C$ and $D$ ) on GABA-negative pyramidal cell dendrites $\left(d_{P}\right)$. The ultrastructure of these synapses was similar to those formed by the CR-containing terminals originating from the nucleus reuniens thalami. Scale bars: $A-D, 0.5 \mu \mathrm{m} ; E, 1 \mu \mathrm{m}$. 


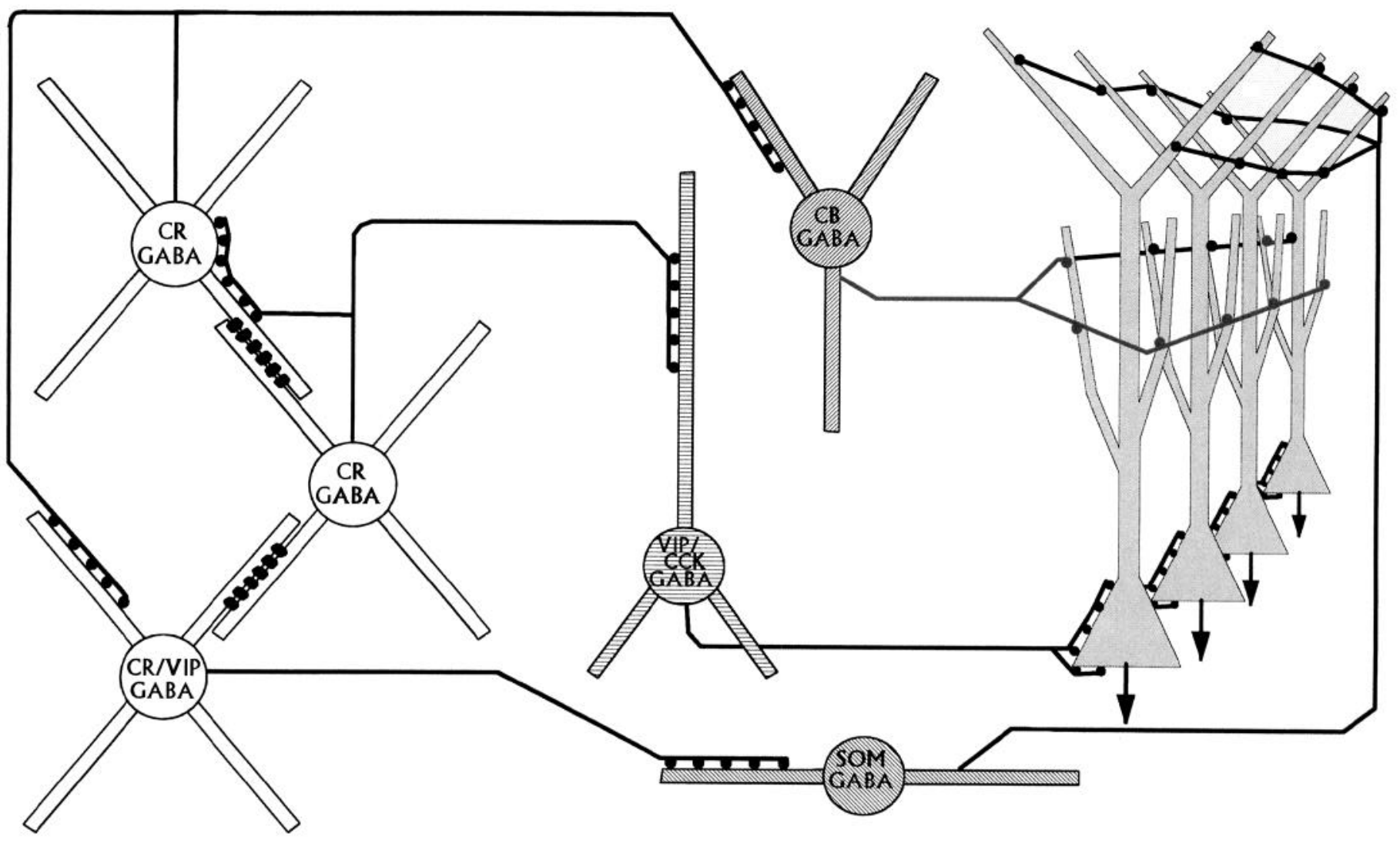

\section{"DISINHIBITORY" CELLS INHIBITORY CELLS PRINCIPAL CELLS}

Figure 8. Hippocampal microcircuits consist of three major components: (1) the principal cells (gray cells) account for the majority of cortical cells and form long-range as well as local, excitatory connections; (2) diverse groups of inhibitory cells (different hatching), which control the activity of principal cells by exerting inhibition on different somato-dendritic domains; and (3) "disinhibitory" neurons (open cells). The CR-IR "disinhibitory" neurons are massively interconnected by dendro-dendritic (parallel bars on their dendrites) and axo-dendritic contacts with each other. As a result of mutual synaptic interconnection and dendritic coupling, the activity of these neurons is likely to become rhythmic and synchronized. This oscillation is then conveyed to large populations of pyramidal cells via different inhibitory cell populations. Both dendritic (CB-IR cells) and perisomatic (VIP/CCK-IR cells) inhibition of principal cells may be synchronized in this manner. It is important to note here that, for the sake of clarity, several components of the hippocampal inhibitory circuitry have been ignored to obtain this diagram, which is intended to summarize the present findings. Other subsets of inhibitory cells (e.g., conventional basket cells) are also known to provide input to interneurons, although their major targets remain pyramidal cells. $C R$, Calretinin; $C B$, calbindin $\mathrm{D}_{28 \mathrm{k}}$.

border. The majority of these horizontal cells are immunoreactive both for metabotropic glutamate receptor 1a (mGluR1a) and SOM (Baude et al., 1993). SOM-containing cells were demonstrated to be GABAergic (Somogyi et al., 1984; Kosaka et al., 1988) and to innervate distal apical dendrites of pyramidal cells (Kunkel and Schwartzkroin, 1988; Léránth et al., 1990). These findings imply that a subpopulation of CR-IR cells, also containing VIP, innervate SOM-IR cells, which, in turn, terminate on the distal apical dendrites of pyramidal cells.

We conclude that CR-IR cells innervate at least three distinct interneuron populations, which terminate in different somadendritic domains of principal cells: VIP(CCK)-IR basket cells, CB-IR cells, and SOM-IR cells, which terminate in the perisomatic, in the mid-distal dendritic and in the distal apical dendritic regions, respectively (see Fig. 8).

Cerebral cortical networks were thought to consist of two basic components: (1) a profusely interconnected ensemble of principal cells that accounts for the majority of cortical neurons, and (2) diverse groups of interneurons that control the firing and afferent input of principal cells by exerting inhibition in different somadendritic domains (Han et al., 1993; Buhl et al., 1994; Miles et al., 1994). CR-IR cells account for a considerable portion (13\%; Miettinen et al., 1992) of hippocampal GABAergic cells; therefore, we suggest that a third component should be added to the scheme of cortical architecture. We refer to this third component as "disinhibitory" cells only on the basis of their connectivity. However, the net effect of their activity on principal cell populations may well be other than disinhibition. As suggested by Cobb et al. (1995), inhibition may reset, and thus synchronize, the activity of pyramidal cells. Likewise, CR-IR cells are likely to time the activity of inhibitory neurons, and thereby may disinhibit, or synchronize inhibition (see below) of large principal cell populations (Fig. 8).

\section{Mutual inhibition and dendro-dendritic connectivity of CR-IR cells may generate synchronous rhythmic activity}

A unique feature of CR-IR cells is their extensive interconnectivity. The long dendro-dendritic junctions may be the result of 
development from common ancestor cells, and during radial migration their dendrites may remain connected. However, the observations that dendro-dendritic contacts can be found between horizontally distant cells and that these contacts are rarely seen until postnatal day 9-10 (L. Acsády, personal communication) argue against this interpretation. The second observation implies that the dendrites of the cells find each other actively during development. A similar active mechanism might explain the precise connectivity of the axons as well.

The possible functional role of this extensive interconnectivity is a puzzling question. Several modeling studies demonstrated that mutual inhibition among pairs or clusters of inhibitory neurons may result in rhythmic inhibitory cell activity (Perkel and Mulloney, 1974; Mulloney et al., 1981; Wang and Rinzel, 1993; Whittington et al., 1995). In vitro measurements and computer modeling demonstrated that reciprocally interconnected inhibitory cells tonically activated by metabotropic glutamate receptors show rhythmic, synchronous firing, and might generate $40 \mathrm{~Hz}$ oscillation in the hippocampus (Whittington et al., 1995). The authors also showed that $\mathrm{GABA}_{\mathrm{A}}$ receptormediated inhibition is necessary for the generation of this activity pattern. Similar rhythmic activity can be evoked in interneurons by 4-AP application in hippocampal slices, which may be brought about by excitatory $\mathrm{GABA}_{\mathrm{A}}$ receptor-mediated postsynaptic potentials (Michelson and Wong, 1991). Regardless of whether the excitatory or inhibitory mechanism plays a role in rhythm generation, both mechanisms require an interconnected inhibitory cell network within the hippocampus.

Mutually connected inhibitory neurons are thought to be responsible for rhythm generation in the nucleus reticularis thalami (Montero and Singer, 1984; Deschênes et al., 1985) and in invertebrates (Getting, 1989). However, no interneuron types with similar properties have been described in the cerebral cortex before. The numerous axo-dendritic connections among CR-IR cells make this group a candidate for generating an oscillatory inhibitory cell activity in the hippocampus, which can be already synchronous in itself as shown by Whittington et al. (1995). The rather extensive dendrodendritic connections, which might span the entire hippocampus, can further increase the synchrony of firing, as suggested by models demonstrating that electrical coupling of cells ensures synchrony of rhythmic activity (Mulloney et al., 1981). Gap junctions between hippocampal interneurons are most often accompanied by puncta adherentia (Kosaka and Hama, 1985); thus, it is possible that gap junctions, not readily detectable in our material, surround the puncta adherentia. In addition, ephaptic interactions (Van der Loos, 1974; Yim et al., 1986) among dendrites running attached for over $100 \mu \mathrm{m}$ are also possible.

The importance of rhythmic, synchronous cortical activity has been recently emphasized in connection with feature binding and temporal coding (Gray et al., 1990; Buzsáki et al., 1992; Engel et al., 1992; Hopfield, 1995). The connectivity of the CR-IR cells suggests that they might play an important role in the generation of cortical rhythms. The rhythm generated by the reciprocal connections of "disinhibitory" cells is conveyed by several distinct groups of inhibitory neurons to different domains of pyramidal cells, giving a background priming to lock into temporally coherent oscillations.

\section{REFERENCES}

Acsády L, Arabadzisz D, Freund TF (1996a) Correlated morphological and neurochemical features identify different subset of VIP-immunoreactive interneurons in rat hippocampus. Neuroscience, in press.

Acsády L, Görcs TJ, Freund TF (1995b) Different populations of VIPimmunoreactive interneurons are specialized to control pyramidal cells or interneurons in the hippocampus. Neuroscience, in press.
Baimbridge KG, Miller JJ (1982) Immunohistochemical localization of calcium-binding protein in the cerebellum, hippocampal formation and olfactory bulb of the rat. Brain Res 245:223-229.

Baude A, Nusser Z, David J, Roberts B, Mulvihill E, McIlhinney RAJ, Somogyi P (1993) The metabotropic glutamate receptor (mGluR1a) is concentrated at perisynaptic membrane of neuronal subpopulations as detected by immunogold reaction. Neuron 11:771-787.

Buhl FH, Halasy K, Somogyi P (1994) Diverse sources of hippocampal unitary inhibitory postsynaptic potentials and the number of synaptic release sites. Nature 368:823-828.

Buzsáki G, Horváth Z, Urioste R, Hetke J, Wise K (1992) High-frequency network oscillation in the hippocampus. Science 256:1025-1027.

Celio MR (1990) Calbindin D-28k and parvalbumin in the rat nervous system. Neuroscience 35:375-475.

Cobb SR, Buhl EH, Halasy K, Paulsen O, Somogyi P (1995) Synchronization of neuronal activity in hippocampus by individual GABAergic interneurons. Nature 372:75-78.

DeFelipe J, Hendry SHC, Jones EG (1989) Synapses of double bouquet cells in monkey cerebral-cortex visualized by calbindin immunoreactivity. Brain Res 503:49-54.

Deschênes M, Madariaga-Domich A, Steriade M (1985) Dendrodendritic synapses in the cat reticularis thalami nucleus: a structural basis for thalamic spindle synchronization. Brain Res 334:165-168.

Engel AK, Konig P, Kreitcr AK, Schillen TB, Singer W (1992) Temporal coding in the visual cortex-new vistas on integration in the nervous system. Trends Neurosci 15:218-226.

Freund TF, Antal M (1988) GABA-containing neurons in the septum control inhibitory interneurons in the hippocampus. Nature 336:170-173.

Freund TF, Gulyás AI, Acsády L, Görcs T, Tóth K (1990) Serotonergic control of the hippocampus via local inhibitory interneurons. Proc Natl Acad Sci USA 87:8501-8505.

Getting PA (1989) Emerging principles governing the operation of neural networks. Annu Rev Neurosci 12:185-204.

Gray CM, Engel AK, Konig P, Singer W (1990) Stimulus-dependent neuronal oscillations in cat visual cortex: receptive field properties and feature dependence. Eur J Neurosci 2:607-619.

Gulyás AI, Görcs TJ, Freund TF (1990) Inncrvation of different peptidecontaining neurons in the hippocampus by GABAergic septal afferents. Neuroscience 37:31-44.

Gulyás AI, Tóth K, Dános P, Freund TF (1991) Subpopulations of GABAergic neurons containing parvalbumin, calbindin-d28k, and cholecystokinin in the rat hippocampus. J Comp Neurol 312:371-378.

Gulyás AI, Miettinen R, Jacobowitz DM, Freund TF (1992) Calretinin is present in non-pyramidal cells of the rat hippocampus. I. A new type of neuron specifically associated with the mossy fibre system. Neuroscience 48:1-27.

Gulyás AI, Miles R, Hájos N, Freund TF (1993a) Precision and variability in postsynaptic target selection of inhibitory cells in the hippocampal CA3 region. Eur J Neurosci 6:1729-1751.

Gulyás AI, Miles R, Sík A, Tóth K, Tamamaki N, Freund TF (1993b) Hippocampal pyramidal cells excite inhibitory neurons through a single release site. Nature 366:683-687.

Hájos N, Acsády L, Freund TF (1996) Target selectivity and neurochemical characteristics of VIP-immunoreactive interneurons in the rat dentate gyrus. Eur $\mathbf{J}$ Neurosci, in press.

Halasy K, Somogyi P (1993) Subdivision in the multiple GABAergic innervation of granule cells in the dentate gyrus of the rat hippocampus. Eur J Neurosci 5:411-429.

Han ZS, Buhl EH, Lörinczi Z, Somogyi P (1993) A high degree of spatial selectivity in the axonal and dendritic domains of physiologically identified local-circuit neurons in the dentate gyrus of the rat hippocampus. Eur J Neurosci 5:395-410.

Hodgson AJ, Penke B, Erdei A, Chubb IV, Somogyi P (1985) Antisera to $\gamma$-aminobutyric acid. I. Production and characterization using a new model system. J Histochem Cytochem 33:229-239.

Hopfield JJ (1995) Pattern recognition computation using action potential timing for stimulus representation. Nature 376:33-36.

Jacobowitz DM, Winsky L (1991) Immunocytochemical localization of calretinin in the forebrain of the rat. $\mathbf{J}$ Comp Neurol 304:198-218.

Katsumaru H, Kosaka T, Heizmann CW, Hama K (1988) Immunocytochemical study of GABAergic neurons containing the calcium-binding protein parvalbumin in the rat hippocampus. Exp Brain Res 72:347-362.

Kawaguchi Y, Hama K (1987) Two subtypes of non-pyramidal cells in rat hippocampal formation identified by intracellular recording and HRP injection. Brain Res 411:190-195. 
Köhler C (1982) Distribution and morphology of vasoactive intestinal polypeptide-like immunoreactive neurons in regio superior of the rat hippocampal formation. Neurosci Lett 33:265-270.

Köhler C, Eriksson L, Davies S, Chan-Palay V (1986) Neuropeptide Y innervation of the hippocampal region in the rat and monkey brain. J Comp Neurol 244:384-400.

Kosaka T, Hama K (1985) Gap junctions between non-pyramidal cell dendrites in the rat hippocampus (CA1 and $\mathrm{CA} 3$ regions): a combined Golgi-electron microscopy study. J Comp Neurol 231:150-161.

Kosaka T, Kosaka K, Tateishi K, Hamaoka Y, Yanaihara N, Wu JY, Hama K (1985) GABAergic neurons containing CCK-8-like and/or VIP-like immunoreactivities in the rat hippocampus and dentate gyrus. J Comp Neurol 239:420-430.

Kosaka T, Katsumaru H, Hama K, Wu JY, Heizmann CW (1987) GABAergic neurons containing the $\mathrm{Ca}^{2+}$-binding protein parvalbumin in the rat hippocampus and dentate gyrus. Brain Res 419:119-130.

Kosaka T, Wu JJ, Benoit R (1988) GABAergic neurons containing somatostatin-like immunoreactivity in the rat hippocampus and dentate gyrus. Exp Brain Res 71:388-398.

Köves K, Arimura A, Göres TG, Somogyvári-Vígh $\Lambda$ (1991) Comparative distribution of immunoreactive pituitary adenylate cyclase activating polypeptide and vasoactive intestinal polypeptide in rat forebrain. Neuroendocrinology 54:159-169.

Kunkel DD, Schwartzkroin PA (1988) Ultrastructural characterization and GAD co-localization of somatostatin-like immunoreactive neurons in CA1 of rabbit hippocampus. Synapse 2:371-381.

Lacaille JC, Schwartzkroin PA (1988a) Stratum lacunosum-moleculare interneurons of hippocampal CA1 region. I. Intracellular response characteristics, synaptic responses, and morphology. J Neurosci 8:1400-1410.

Lacaille JC, Schwartzkroin PA (1988b) Stratum lacunosum-moleculare interneurons of hippocampal CAl region. II. Intrasomatic and intradendritic recordings of local circuit synaptic interactions. J Neurosci 8:1411-1424.

Lacaille JC, Mueller AL, Kunkel DD, Schwartzkroin PA (1987) Local circuit interactions between oriens/alveus interneurons and CA1 pyramidal cells in hippocampal slices: electrophysiology and morphology. J Neurosci 7:1979-1993.

Léránth C, Frotscher M, Tömböl T, Palkovits M (1984) Ultrastructure and synaptic connections of vasoactive intestinal polypeptide-like immunoreactive non-pyramidal neurons and axon terminals in the rat hippocampus. Neuroscience 12:531-542.

Léránth C, Malcolm AJ, Frotscher M (1990) Afferent and efferent synaptic connections of somatostatin-immunoreactive neurons in the rat fascia dentata. J Comp Neurol 295:111-122.

Maccaferri G, McBain CJ (1995) Passive propagation of LTD to stratum oriens-alveus inhibitory neurons modulates the temporoammonic input to the hippocampal CA1 region. Neuron 15:137-145.

Maglóczky Z, Acsády L, Freund TF (1994) Principal cells are the postsynaptic targets of supramammillary afferents in the hippocampus of the rat. Hippocampus 4:322-334.

McBain CJ, DiChiara TJ, Kauer JA (1994) Activation of metabotropic glutamate receptors differentially affects two classes of hippocampal interneurons and potentiates excitatory synaptic transmission. J Neurosci $14: 4433-4445$.

Michelson HB, Wong RK (1991) Excitatory synaptic responses mediated by GABA-A receptors in the hippocampus. Science 253:1420-1422.

Miettinen R, Gulyás AI, Baimbridge KG, Jacobowitz DM, Freund TF (1992) Calretinin is present in non-pyramidal cells of the rat hippocampus. 2. Co-existence with other calcium binding proteins and GABA. Neuroscience 48:29-43.

Miles R, Tóth K, Gulyás AI, Hájos N, Freund TF (1994) Functional differences between dendritic and perisomatic hippocampal inhibition. Soc Neurosci Abstr 20:301.

Misgeld U, Frotscher M (1986) Postsynaptic-GABAergic inhibition of non-pyramidal neurons in the guinea-pig hippocampus. Neuroscience 19:193-206.

Montero VM, Singer W (1984) Ultrastructure and synaptic relations of neural elements containing glutamic acid decarboxylase (GAD) in the perigeniculate nucleus of the cat. Exp Brain Res 56:115-125.

Mulloney B, Perkel DH, Budelli RW (1981) Motor-pattern production: interaction of chemical and electrical synapses. Brain Res 229:25-33.

Nitsch R, Léránth C (1993) Calretinin immunoreactivity in the monkey hippocampal formation. 2. Intrinsic GABAergic and hypothalamic nonGABAergic systems-an experimental tracing and co-existence study. Neuroscience 55:797-812.
Nunzi MG, Gorio A, Milan F, Freund TF, Somogyi P, Smith AD (1985) Cholecystokinin-immunoreactive cells form symmetrical synaptic contacts with pyramidal and nonpyramidal neurons in the hippocampus. J Comp Neurol 237:485-505.

Perkel DH, Mulloney B (1974) Motor pattern production in reciprocally inhibitory neurons exhibiting postinhibitory rebound. Science 185:181-183.

Ribak CE, Nitsch R, Seress L (1990) Proportion of parvalbumin-positive basket cells in the GABAergic innervation of pyramidal and granule cells of the rat hippocampal formation. J Comp Neurol 300:449-461.

Rogers JH (1989) Two calcium-binding proteins mark many chick sensory neurons. Neuroscience 31:697-709.

Rogers JH (1992) Immunohistochemical markers in rat cortex: colocalization of calretinin and calbindin-D28k with neuropeptides and GABA. Brain Res 587:147-157.

Sík A, Tamamaki N, Freund TF (1993) Complete axon arborization of a single CA3 pyramidal cell in the rat hippocampus, and its relationship with postsynaptic parvalbumin-containing interneurons. Eur J Neurosci $5: 1719-1728$

Sík A, Penttonen M, Ylinen A, Buzsáki G (1995) Hippocampal CA1 interneurons: an in vivo intracellular labelling study. J Neurosci 15:6651-6665.

Sloviter RS (1989) Calcium-binding protein (calbindin-D28k) and parvalbumin immunocytochemistry: localization in the rat hippocampus with specific reference to the selective vulnerability of hippocampal neurons to seizure activity. J Comp Neurol 280:183-196.

Sloviter RS, Nilaver G (1987) Immunocytochemical localization of GABA-, cholecystokinin-, vasoactive intestinal polypeptide-, and somatostatin-like immunoreactivity in the area dentata and hippocampus of the rat. J Comp Neurol 256:42 -60.

Sloviter S, Sollas AL, Barbaro NM, Laxer KD (1991) Calcium binding protcin (calbindin-D28k) and parvalbumin immunocytochemistry in the normal and epileptic human hippocampus. J Comp Neurol 308:381-396.

Somogyi P, Hodgson AJ (1985) Antisera to $\gamma$-aminobutyric acid. III. Demonstration of GABA in Golgi-impregnated neurons and in conventional electron microscopic sections of cat striate cortex. J Histochem Cytochem 33:249-257.

Somogyi P, Soltész I (1986) Immunogold demonstration of GABA in synaptic terminals of intracellularly recorded, horseradish peroxidasefilled basket cells and clutch cells in the cat's visual cortex. Neuroscience 19:1051-1065.

Somogyi P, Hodgson AJ, Smith AD, Nunzi MG, Gorio A, Wu JJ (1984) Different populations of GABAergic neurons in the visual cortex and hippocampus of cat contain somatostatin- or cholecystokininimmunoreactive material. J Neurosci 4:2590-2603.

Somogyi P, Nunzi MG, Smith AD (1983) A new type of specific interneuron in the monkey hippocampus forming synapses exclusively with the axon initial segments of pyramidal cells. Brain Res 259:137-142.

Tóth K, Freund TF (1992) Calbindin D28k-containing nonpyramidal cclls in the rat hippocampus: their immunoreactivity for GABA and projection to the medial septum. Neuroscience 49:793-805.

Tóth K, Freund TF, Miles R (1995) Septal stimulation suppresses hippocampal synaptic inhibition in a combined slice preparation. Soc Neurosci Abstr 21:473.

Van der Loos H (1974) Interneuronal connectivity. Dendrodendritic junctions. Neurosci Res Program Bull 12:86-90.

Wang XJ, Rinzel J (1993) Spindle rhythmicity in the reticularis thalami nucleus: synchronization among mutually inhibitory neurons. Neuroscience 53:899-904.

Whittington MA, Traub RD, Jeffreys JGR (1995) Synchronized oscillations in interneurons driven by metabotropic glutamate receptor activation. Nature 373:612-615.

Winsky L, Nakata H, Martin BM, Jacobowitz DM (1989) Isolation, partial amino acid sequence, and immunohistochemical localization of a brain-specific calcium-binding protein. Proc Natl Acad Sci USA 86:10139-10143.

Wouterlood FG, Bol JG, Steinbusch HW (1987) Double-label immunocytochemistry: combination of anterograde neuroanatomical tracing with Phaseolus vulgaris leucoagglutinin and enzyme immunocytochemistry of target neurons. J Histochem Cytochem 35:817-823.

Wouterlood FG, Saldana E, Witter MP (1990) Projection from the nucleus reuniens thalami to the hippocampal region: light and electron microscopic tracing study in the rat with the anterograde tracer Phaseolus vulgaris-leucoagglutinin. J Comp Neurol 296:179-203.

Yim CC, Krnjevic K, Dalkara T (1986) Ephaptically generated potentials in CA1 neurons of rat's hippocampus in situ. J Neurophysiol $56: 99-122$ 